\title{
Terrorism threat in Belgium: The resilience of Belgian citizens and the protection of governmental reputation by means of communication
}

\author{
Hannelore Crijns*, Veroline Cauberghe, Liselot Hudders \\ Department of Communication Sciences, Ghent University, Belgium
}

\section{A R T I C L E I N F O}

\section{Article history:}

Received 20 May 2016

Received in revised form

22 September 2016

Accepted 25 October 2016

Available online $\mathrm{xxx}$

\section{Keywords:}

Information seeking and processing

behavior

Risk perception

Negative affective responses

Reputation

Institutional trust

Responsibility

\begin{abstract}
A B S T R A C T
In November 2015, the terrorism threat in Belgium confronted both citizens and the government with a situation characterized by high uncertainty. In this context, a national survey was conducted among 805 respondents, with three purposes. First, this case study aimed to explore how Belgians deal with the threat by examining if they change their behavior in public places and seek information about the threat. Second, we investigated why people seek and process information about the terrorism threat based on three determinants, namely their level of involvement with the threat, the expert efficacy of the government, and attitudes towards mass media communication. Finally, this study elaborated on perceived governmental efficacy, researching how governmental reputation is affected through institutional trust and governmental responsibility. The results show that the terrorism threat leads citizens to be more alert in public places and participate less in mass events. Moreover, one fifth stopped traveling by public transport. It was found that Belgian citizens also searched for information several times a day, mostly via traditional media such as television and radio. Furthermore, based on structural equation modelling, we found that information seeking and processing behavior is determined by the cognitive assessment of the risk. This cognitive risk assessment is in turn positively influenced by risk involvement and perceived governmental expert efficacy. However, if the mass media are seen to focus too much on drama and sensationalism then the perception of risk decreases, and this in turn reduces information seeking behavior. In addition, results show that a perception of governmental expert efficacy is able to increase trust and decrease the level of governmental responsibility, which is in turn beneficial for governmental reputation. The implications of these findings are discussed.
\end{abstract}

(c) 2016 Elsevier Inc. All rights reserved.

\section{Introduction}

The majority of Belgians consider terrorism to be the most important challenge for internal security within the European Union (Eurobarometer, 2015). ${ }^{1}$ Several incidents in Belgium have confirmed the validity of this concern. The terrorist attacks

\footnotetext{
* Corresponding author at: Department of Communication Sciences, Ghent University, Korte Meer 9, 9000 Ghent, Belgium.

E-mail address: hannelore.crijns@ugent.be (H. Crijns).

1 The Eurobarometer is a barometer used to measure the attitudes of Europeans towards security conducted in March 2015. Results showed terrorism is the highest-ranked challenge in Belgium (65\%) followed by organized crime (45\%), cybercrime (37\%), management of the EU's external borders (34\%), and natural and man-made disasters (30\%).
} 
in Paris in November 2015 were coordinated from within Belgium. Moreover, Salah Abdeslam, a terrorist involved in the Parisian terrorist attacks was arrested in the capital city Brussels. Hence, terrorism has formed a significant threat in Belgium, characterized by some unique features that determine it as a risk management issue. It produced significant uncertainty in two different ways, namely the likelihood that a terrorist attack will take place and the extent of its consequences (Kunreuther, 2002). Consequently, terrorism became a main concern for Belgian citizens and a top priority of the Belgian federal government.

Unfortunately, the government could not prevent the terrorist attacks that took place, four months after the attacks in Paris, in Brussels Airport and in the metro station in Maalbeek at the heart of the capital city of Belgium. This case study however was conducted before these attacks, in the context of a terrorism threat that formed a unique challenge for both the government and Belgian citizens, who must deal with a very uncertain situation. Unlike other types of crisis, terrorism forms a relatively new threat because it is often unknown who exactly the enemy is. Hence, the threat is constantly evolving and hard to assess (Gray \& Ropeik, 2002; Innes, 2006). In this context, it is possible that Belgians will change their behavior in public places by avoiding public transport for example (Nellis, 2009) or engaging in information seeking and processing behavior. The latter enables citizens to reduce their feelings of uncertainty and increase their feelings of control (Ford, 2004; Kievik \& Gutteling, 2011). Hence, by seeking and processing information about the threat, Belgian citizens try to form a resilient community that is able to bounce back after a possible terrorist attack (Carpenter, 2015).

Resilience is important to consider in the context of terrorism threats as a terrorist attacks are not always preventable. However, the government and other authorities can provide information to citizens in order to anticipate threats, minimize the vulnerability of citizens, and help them to recover from attacks when they occur (Patin, 2015). In this process, communication is of crucial importance as it can reduce damage and loss of life, and minimize rumors and misinformation (Longstaff and Yang, 2008; Norris, Stevens, Pfefferbaum, Wyche, \& Pfefferbaum, 2008). The mass media also play an important role in this process and should do so responsibly, as sensationalizing information about risk rather than providing structural messages can hinder response and recovery (Frisby, Veill, \& Sellnow, 2014).

In contrast to other studies, which primarily focus on how organizations deal with risks or crises (Liu \& Fraustino, 2014), this case-study takes the perspective of the public. Namely, by investigating how citizens cope with a terrorism threat. More specifically, we will first examine to what extent Belgian citizens change their behavior in public places because of the threat and seek information about the threat. Second, this case study will elaborate on information seeking and processing behavior by investigating the factors that trigger this behavior. More specifically, we will analyze how the level of involvement with the terrorism threat, governmental expert efficacy, and attitudes towards mass media communication influence the cognitive and affective responses of people and subsequently their information seeking behavior. Hereby, we will gain insights in what drives information seeking and processing behavior of people towards the risk, which is crucial for improving risk and crisis communication (Slovic, 1987; Rogers, Amlôt, Rubin, Wessely, \& Krieger, 2007; Lee \& Lemyre, 2009).

Moreover, this case study investigates the impact of the attitudes towards the mass media and perceived governmental efficacy on the cognitive and affective assessment of the risk. In doing so, the study sheds light on a so far indecisive topic, namely how communication is able to form the cognitive and affective perceptions of people and hence their information seeking and processing behavior (Griffin, Yang, Ter Huurne, Boerner, Ortiz, \& Dunwoody, 2008). For example, in the Risk Information Seeking and Processing (RISP) model (Griffin, Dunwoody, \& Neuwirth, 1999), beliefs about mass media coverage of a risk are referred to as relevant channel beliefs. However, research on the impact of these beliefs remains exploratory (Griffin et al., 2008), and is often inconclusive with regards to the impact on information seeking and processing behavior, and whether positive or negative beliefs result in more or less information seeking and processing (Griffin, Powell, Dunwoody, Neuwirth, Clark, \& Novotny, 2004; Griffin et al., 2008; Yang, 2012). Hence, it is important to clarify the impact of perceptions about mass media coverage in the context of the terrorism threat. Nevertheless, besides the mass media, the government and its representative experts (i.e., ministers) are crucial communicating actors during a terrorism threat. Therefore, we will also investigate the impact of governmental expert efficacy on information seeking and processing behavior.

Finally, we have to recognize that the terrorism threat is not only challenging for Belgian citizens, but also for the Belgian federal government and its experts, who have the delicate task of communicating information about the terrorism threat whilst avoiding interruptions to the investigations of police services. Therefore, the third aim of this study is to investigate how governmental communication affects its reputation; this is a very important asset for the government as it reflects the level of public approval towards their actions (Watson, 2007). In particular, we will research the mediating roles of institutional trust (Ter Huurne \& Gutteling, 2008; Liu, Bartz, \& Duke, 2016) and governmental responsibility (Coombs, 2007), which are both important factors in a context of high uncertainty.

First, in order to get a better understanding of the context of the terrorism threat in Belgium, the following paragraphs give a short overview of the facts related to this.

\section{Situational background of the terrorism threat in Belgium}

On the 15th of January 2015, the Belgian federal police were able to neutralize a terrorist cell of Islamic State located in the Belgian city Verviers. The terrorists were organizing an attack against the Belgian police services (Eeckhaut, Vanhecke, \& Tack, 2015). Furthermore, on the 13th of November 2015, terrorists conducted the worst attack against France since World War II. In Paris, the capital of France, 129 people died and 352 people were injured, 99 with injuries that were life threatening. 
People were shot in the venue Bataclan and in several Parisian restaurants, and one suicide bomber exploded a device close to the Stade de France (Bergmans, 2015). The terrorist attack was claimed by Islamic State.

A hunt to find Salah Abdeslam was launched after the Parisian attacks. Salah Abdeslam, a Belgian citizen with Moroccan roots, had lived in Brussels, the capital city of Belgium, for most of his life. According to Islamic State, he was the only living terrorist connected to the Parisian attacks. Abdeslam fled back to Belgium on the 14th of November 2015, and his presumed presence in Brussels was one of key factors behind a security lockdown of the city. The Belgian federal government feared an imminent Paris-style attack, and therefore the security alert was raised to a maximum in Brussels and to the second highest level in the rest of the country. Metro stations and city schools were closed and 300 additional police officers and 200 soldiers were deployed in the capital city. Belgium became the heart of investigations into the Paris' attacks (Rose \& Blenkinsop, 2015). The mass media in Belgium gave extensive attention to the terrorism threat through live reporting and by releasing extra news items. They formed one of the primary news sources for Belgian citizens. Moreover, the government was communicating very often via the mass media about the terrorism threat.

On the 22th of March 2016, after the current study was established, the terrorism threat became a crisis as terrorist attacks took place on the national airport in Brussels and a metro station in the city center. Thirty-two people lost their lives and almost 300 people were injured.

\section{Literature review}

\subsection{How are Belgian citizens coping with the terrorism threat?}

According to Heath, Lee and Ni (2009), people have different levels of concern based on the belief that they or the ones they love could be harmed by the event. For a terrorist attack the level of concern was $72 \%$, which is higher than that of other investigated risks such as a storm or a chemical release. Hence, people will try to find a way to cope with this high concern. In the following paragraphs two different coping strategies will be discussed, namely behavior in public places and information seeking behavior.

\subsubsection{Behavior in public places}

Based on the insights of risk communication literature, we expect that Belgians can deal with the terrorism threat in several ways. According to Witte's (1992) Extended Parallel Processing Model (EPPM), a threat appeal triggers a process in which people appraise two components, namely the perceived threat of the risk and the perceived efficacy. The perceived threat is determined by the perceived susceptibility to being directly affected by the threat, and the perceived severity of the threat. This perception of threat is also referred to as the risk perception or cognitive assessment of the risk (ter Huurne, 2008). Perceived efficacy is the feeling of personal control, and consists of self-efficacy and response-efficacy. Self-efficacy refers to the individual's belief in following the recommendations of the message, whereas response-efficacy refers to the individual's belief that the recommended response will be effective in dealing with the threat. A danger control process is initiated only when both the threat and the efficacy are perceived as high. This process results in the motivation of individuals to protect themselves. Hence, they accept the message and adopt the recommended protective behavior (Witte, 1992). This is unlikely to occur when the threat is perceived as high but the efficacy as low. In this case, a fear control process is initiated. In this case, the negative feelings of fear and worry are too high, and they cannot be reduced by the recommended behavior as people feel incapable of following this.

The first research question will investigate to what extent Belgians changed their behavior in public places, specifically by avoiding mass events and public transport (Lee, Gibson, Markon, \& Lemyre, 2009). We argue that people change their behavior in public places, following the advice of government experts, in an attempt to enhance their self-efficacy. However, response-efficacy may be low because, in times of a terrorist threat, people are not really safe anywhere. Hence, the first research question asks:

$\mathbf{R Q}_{1}$ : To what extent do Belgians adapt their behavior in public places because of the terrorism threat?

\subsubsection{Information seeking behavior}

Nevertheless, people might also try to cope with the threat instead of avoiding it. A possible way to increase the feeling of control over the threat of terrorism is to seek information about it (Ford, 2004; Kievik \& Gutteling, 2011; Palenchar \& Heath, 2002). Therefore, we also formulate the following research question:

$\mathbf{R Q}_{2}$ : To what extent do Belgians engage in information seeking behavior because of the terrorism threat?

\subsection{Why are Belgians coping with the terrorism threat? Determinants of information seeking and processing behavior}

Next, we will examine some factors which might drive Belgians' information seeking and processing behavior about the terrorism threat. In risk communication, several models have been used to investigate the determinants that influence information seeking and processing behavior; example are the EPPM model discussed earlier (Witte, 1992), the Risk Information Seeking and Processing (RISP) model (Griffin et al., 1999), the Framework For Risk Information and Seeking (FRIS) model (ter Huurne, 2008), and the Planned Risk Information Seeking Model (PRISM) (Kahlor, 2010). All these models share the assumption that people make appraisals of a certain risk both in a cognitive and affective way, which in turn positively 
influences their risk information seeking behavior. Moreover, these models also suggest several factors that influence the cognitive and/or affective processing of the risk. Next, we will elaborate on three factors that might have an impact on the cognitive and affective processing of the terrorism threat, and consequently influence information seeking behavior.

\subsubsection{Involvement with the terrorism threat}

Involvement refers to a personal interest that results from the belief that a threat might have significant consequences for one's life (Andrews, Durvasula, \& Akhter, 1990; Cho \& Boster, 2005). In other words, involvement refers to the feeling that someone's interest is at stake (Palenchar, Heath, \& Orberton, 2005). Involvement has been found to be fundamental in explaining how and why people seek, process, and use information (Grunig, 1989; Heath \& Douglas, 1990; Palenchar \& Heath, 2000; Petty \& Caccioppo, 1981, 1986). When people are confronted with a risk, such as a terrorism threat, their problem recognition is likely to rise when they think their self or altruistic interests are affected (ter Huurne, 2008).

The more people think an event will have an impact on the self or a loved one, the greater their level of involvement will be. This is important for risk communication because when people are highly involved they are more willing to think and communicate about an issue (Kunreuther, Easterling, Desvousges, \& Slovic, 1990; Heath \& Douglas, 1991). The more people are aware of the risk, the more they will be inclined to form or change their attitudes and behavior via central cognitive and message-driven routes (Petty \& Cacioppo, 1981, 1986). This has been formulated in the Elaboration Likelihood Model of Petty and Cacioppo (1986), who are the founders of one of the most important information processing models. This was also argued by Heath, Liao, and Douglas (1995) in the specific context of risk communication. Hence, when involvement is elicited because people think that important future consequences are at stake, people are more likely to process the information in-depth (Kievik, Ter Huurne, \& Gutteling, 2012). Moreover, Kievik et al. (2012) found that higher levels of involvement with the threat results in more information seeking behavior. However, it is unclear if a higher level of involvement increases the cognitive assessment of the risk (ter Huurne, 2008). Therefore, we formulated the following research question:

$\mathbf{R Q}_{3}$ : How is involvement with the terrorism threat linked to the cognitive assessment of the risk?

Unlike the influence of the involvement with the risk on the cognitive assessment of the risk, the FRIS (Ter Huurne \& Gutteling, 2008) model already suggests that higher levels of involvement with the risk increase negative affective responses. Therefore, we expect that:

$\mathbf{H}_{1}$ : The more people feel involved with the terrorism threat, the greater their negative affective responses will be towards the terrorism threat.

In addition to the level of involvement with the terrorism threat, it is also important to consider the communication sources that provide information about the risk to the public (Krewski et al., 2006). According to Ganor and Ben-Lavy (2003) good communication is essential to create resilience. In the case of the terrorism threat, the two primary sources of communication and information were the mass media and the Belgian federal government as represented by its experts.

\subsubsection{Mass media communication}

The mass media form very convenient providers of information in the context of a terrorism threat because of their availability and accessibility (Wray, Kreuter, Jacobsen, Clements, \& Evans, 2004). Therefore, they play a crucial role in the provision of information on the terrorism threat to the public (Krewski et al., 2006). However, often the media do not play a neutral role when reporting about risks. Several authors agree that the media might help to amplify or attenuate a certain risk perception and sense of danger, selecting certain facts or presenting them in a certain way (Kasperson \& Kasperson, 1996; Wray et al., 2004). Therefore, media have been criticized for reporting in a selective and biased way, while emphasizing conflict, dramatic, and sensational aspects (Sandman, 1994). This might in turn have a strong effect on the way people perceive certain risks and how their attitudes and behaviors subsequently change (Stevens, 2010).

Hence, the way people perceive communications about the terrorism threat by the mass media, such as the perceived level of sensationalism, might have an influence on information seeking and processing behavior (Griffin et al., 1999; Kahlor, Dunwoody, Griffin, \& Neuwirth, 2006). However, the specific role that these perceptions play in information seeking and processing behavior, and in particular whether the relationship is positive or negative, remains unclear (Griffin et al., 2008). According to Griffin et al. (2004) further research is necessary to clarify the impact of attitudes towards the sources who deliver risk information. However, several studies investigating risk information seeking and processing behavior do not incorporate this determinant (e.g., ter Huurne, Griffin, \& Gutteling, 2009) or remain exploratory (Griffin et al., 2008).

When discovering the impact of sensational and dramatized mass media coverage, research has shown that sensational information is often thought to elicit negative affective responses such as fear (Gorney, 1992), and inhibit the ability of people to genuinely cognitively assess a certain risk (Covello, Peters, Wojtecki, \& Hyde, 2001). Moreover, news stories which highlight alarming information often result in a greater perceived risk than stories which contain more reassuring information (Signorielli, 1993). However, when people think that the mass media focus too strongly on sensationalism, the dramatized news stories might lower rather than enhance risk perception, and create negative affective responses. Inspired by these insights, we expect that:

$\mathbf{H}_{2}$ : The lower people's evaluation of the communications of the mass media about the terrorism threat, the lower their (a) cognitive assessment of the terrorism threat and (b) negative affective responses towards the terrorism threat will be. 


\subsubsection{Governmental expert efficacy}

Moreover, in times of terrorist threat, governments and more specifically its ministerial representatives have the challenging task of communicating about a very delicate topic. They must find a balance between creating awareness and avoiding inducing fear amongst citizens, whilst avoiding interrupting the actions of the police services (Altheide, 2006; Mythen \& Walklate, 2006). When risks are not personally controllable, as with terrorist attacks (where people have no knowledge about when or how an attack will take place), people are particularly concerned to know what the government is doing or has done to protect them. People can only know this from what the government is communicating about these preventive actions (Ter Huurne \& Gutteling, 2008). The importance of governmental communication is also stressed by a study by Heath et al. (2009), who showed that in risky situations citizens prefer expert advice over that of family of friends.

Emergency management communication is initiated by experts representing the government. The public expects these experts to understand the risk and to be able to predict and mitigate the threat. While the mass media might amplify the drama of the event (i.e., social amplification of the risk, Kasperson, 1992), governmental communication is able to provide what appear to be more objective information to the public regarding efficacy cues (Heath et al., 2009). According to Heath et al. (2009) a crucial determinant of communication in times of emergencies is the persuasiveness of the experts' advice. When the public do not trust the advice of the experts or have the impression that they are at their mercy, they will respond by refusing to accept the experts' advice (Heath, 1997). Therefore, the level of expert efficacy, i.e. the trust in the experts' response advice (Heath \& Lee, 2015, p. 1112), might have an important influence on how people perceive the threat. However, so far studies have not yet investigated if governmental expert efficacy affects the cognitive and affective assessment of the risk. Therefore, we formulate the following research question:

$\mathbf{R Q}_{4}$ : How is perceived governmental expert efficacy linked to (a) the cognitive assessment of the terrorism threat and (b) the negative affective responses towards the terrorism threat?

\subsection{Cognitive and affective assessment of the terrorism threat}

Hence, people assess risks such as the terrorism threat based not only on what they think cognitively (i.e., the analytical system), but also on what they feel affectively (i.e., the experiential system) (Slovic, Finucane, Peters, \& MacGregor, 2004). Kievik et al. (2012) investigated the assumptions of the FRIS model (ter Huurne, 2008) in the context of terrorism. The authors found that a high cognitive risk perception resulted in more information seeking behavior. However, the authors admit that the initial FRIS model suggests an indirect relationship between risk perception and information seeking behavior via negative affective responses (ter Huurne et al., 2009). Moreover, several other well established information seeking and processing models such as the RISP (Griffin et al., 1999) and the EPPM (Witte, 1992) also expect an indirect effect of the cognitive assessment of the risk on information seeking behavior. In these models, the cognitive assessment will have an effect on the negative affective responses people have towards this risk. The higher people assess the risk cognitively (i.e., in terms of severity and susceptibility), the stronger their negative affective responses will be. Moreover, these stronger negative responses in turn initiate more active information seeking behavior (Griffin et al., 2004). Hence, we expect a direct effect of the cognitive assessment of the risk on information seeking behavior and an indirect effect via negative affective responses. Therefore, we assume that:

$\mathbf{H}_{3 a}$ : The higher people's cognitive assessment of the risk of the terrorism threat, the more they will seek information about it.

$\mathbf{H}_{3 b}$ :The higher people's cognitive assessment of the risk of the terrorism threat, the stronger their negative affective responses towards the threat will be.

$\mathbf{H}_{3 b}$ :The higher people's negative affective responses towards the terrorism threat, the more they will seek for information about it.

In Fig. 1 the proposed conceptual model of information seeking and processing behavior is shown:

\subsection{Impact of governmental expert efficacy on the governmental reputation}

Finally, we will also examine how governmental expert efficacy affects governmental reputation in order to gain insights into how the communication about the terrorism threat affects the perceptions people have about the Belgian federal government. Reputation can be described as "a cognitive representation of an organization's actions and results that crystallizes the organization's ability to deliver valued outcomes to its stakeholders" (Fombrun, Gardberg, \& Barnett, 2000, p. 87). Hence, the governmental reputation is a cognitive representation of citizens of the actions and results that the government made with regard to the terrorism threat. It crystallizes the government's ability to protect the citizens from harm. According to Rindova and Fombrun (1998) communication enables the government to show their transparency to the public, which enables people to appreciate the governmental operations better and hence facilitates a better governmental reputation. This is in line with the suggestion of Burke (1999) that one of the primary roles of communication is to sustain, foster, and develop an organization's reputation. Accordingly, we investigate whether perceived governmental expert efficacy affects governmental reputation. We argue that this relationship will be mediated by two different processes: institutional trust and attributed responsibility. 


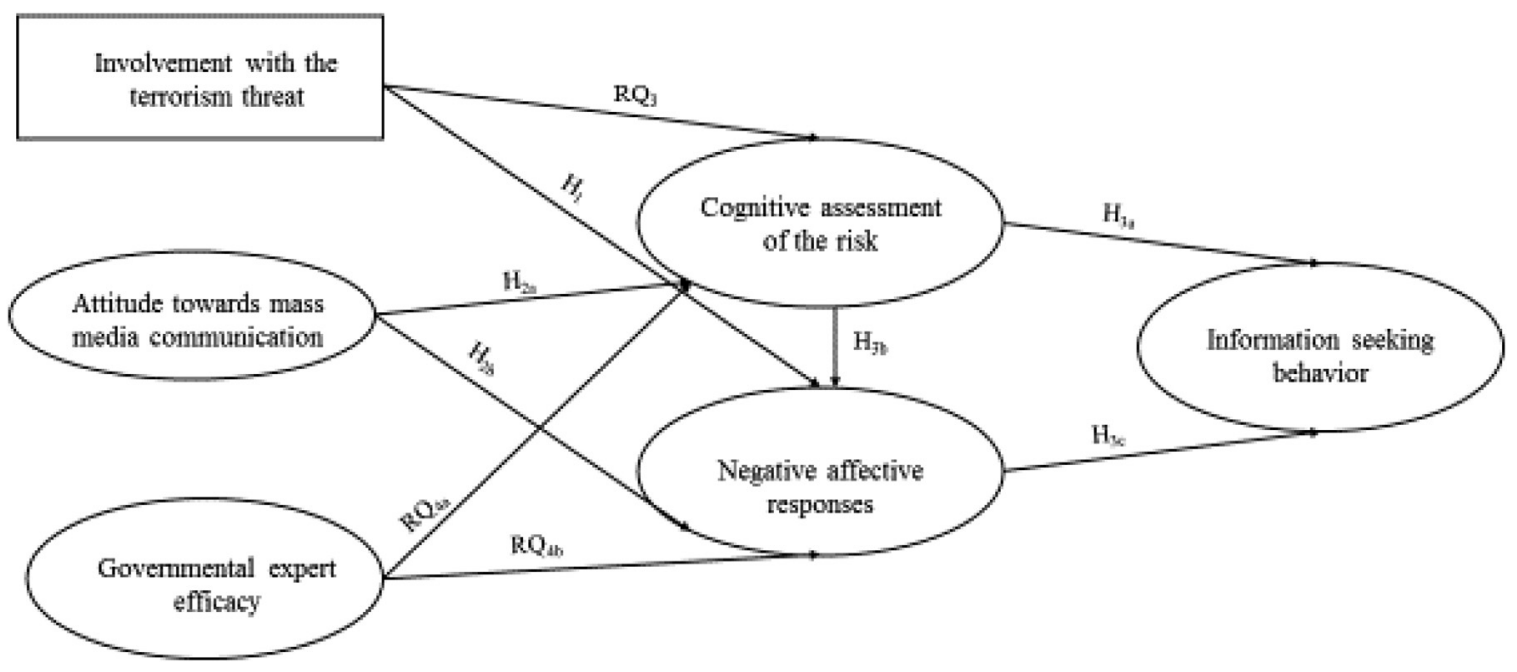

Fig. 1. Proposed conceptual model of information seeking and processing behavior.

\subsubsection{The mediating role of institutional trust}

Liu et al. (2016) describe trust as a key variable when communicating uncertainties. More specifically, in this context, institutional trust is important and can be described as the willingness of individuals to rely on those who have the power and responsibility to make decisions and take actions related to the management of public safety (Siegrist, Cvetkovich, \& Roth, 2000; McComas, 2006; Ter Huurne \& Gutteling, 2008). Hence, applied to the terrorism threat, institutional trust can be seen as the interaction between the government and the citizens, in which the citizens believe that the government does its job and will act according to their best interests (Hosking, 2009; Shore, 2003). Research has shown that the more trust people have in the government, the better they will be able to deal with the uncertain situations, especially in highly uncertain circumstances such as the threat of terrorism (Gray \& Ropeik, 2002; Rogers et al., 2007). Hence, the establishment or re-establishment of trust is crucial for effective risk and crisis communication (Gilles et al., 2011). When risks are not personally controllable, people want to know what the government is doing or has done to protect them. The governmental experts will communicate information about these actions to reassure citizens (Ter Huurne \& Gutteling, 2008). Clear and open communications are therefore essential initiators of trust amongst people and offer the advantage that people are more likely to comply with future messages (Quinn, Kumar, Freimuth, Kidwell, \& Musa, 2009). Therefore, we expect that governmental expert efficacy enhances institutional trust. Moreover, we will also investigate the impact of the level of trust on the governmental reputation, as trust is an important influencing factor in the formation of perceptions of reputation; the more trust people have in an organization, the better the organizational reputation (Fombrun, Gardberg, \& Sever, 2000). Hence, we hypothesize that:

$\mathbf{H}_{4}$ : A higher perceived governmental expert efficacy enhances institutional trust, which in turn is beneficial for the governmental reputation.

\subsubsection{The mediating role of governmental responsibility}

Moreover, as with organizational crisis communication, risk communication might not only have an impact on institutional trust, but also on the amount of responsibility attributed to the government for the risk (De Vocht, 2014). Responsibility is a crucial determinant used by people to form their opinion about organizations, and more specifically their perceptions of organizational reputation (Coombs, 2007). People who are confronted with an uncertain or risky situation are likely to search for underlying causes of events (Dean, 2004; Kelley, 1973). So, when a risk or potential crisis occurs, people will attribute a certain degree of responsibility to the organization or institution confronted with the crisis, in this case the government. The more responsibility is attributed to the government, the more its reputation will suffer (Coombs \& Holladay, 1996; Claeys, Cauberghe, \& Vyncke, 2010). In this study we argue that governments might be able to decrease the level of responsibility attributed to them for the terrorism threat by communicating with expertise to the public. Moreover, we expect this level of responsibility to negatively affect the organizational reputation (Coombs, 2007). Hence, the following hypothesis is formed:

$\mathbf{H}_{5}$ : A higher perceived governmental expert efficacy decreases governmental responsibility, which in turn is beneficial for the governmental reputation.

Fig. 2 demonstrates the proposed conceptual model of the impact of governmental expert efficacy on the governmental reputation via governmental responsibility and institutional trust. 


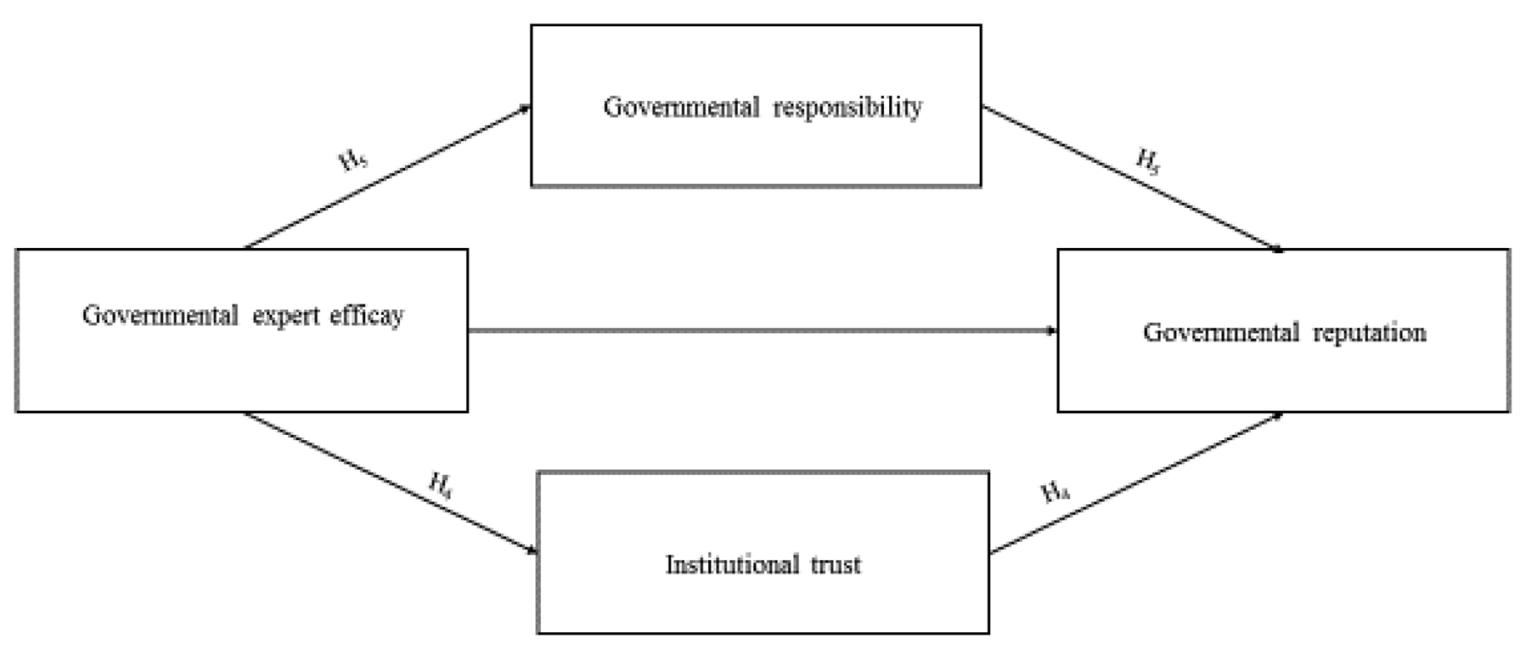

Fig. 2. Proposed conceptual model of the governmental reputation..

\section{Methods}

\subsection{Participants and procedure}

A national research agency sent surveys by mail to a random sample of 805 Belgian residents (467 Flemish residents, 256 residents of Wallonia, and 83 residents of Brussels). Of the respondents, 50.4\% were female and the average age was 47.17 years $(S D=16.15)$, ranging between 18 and 91 years. Since quota sampling is rarely an exact representation of the target population, we weighted our data to improve its representativeness (Rubin, Brewin, Greenberg, Simpson, \& Wessely, 2005).

The data collection is exhibited on the 27th of November 2015, exactly two weeks after the terrorist attacks in Paris. At the moment of the distribution of the survey, the terrorist threat level in Belgium was on the second highest level (i.e., level 3 ), which means that the threat is severe and a terrorist attack is possible and probable to take place. One week before the survey was conducted, on the 21 th of November 2015, the threat level was on the highest level possible (i.e., level 4), which means that the threat is very severe and a terrorist attack very likely to take place.

\subsection{Measurement instrumentation}

A questionnaire was designed to measure each concept presented in the hypotheses and research questions.

Involvement $(M=3.40, S D=1.42)$ is measured based on the item: "How involved do you feel with the terrorism threat?"

The attitude towards mass media communication $(M=3.80, S D=0.87$, alpha $=0.79)$ was measured based on the scale of Yang (2012) with the following items: "The mass media pay too much attention to the terrorism threat"; "The mass media instigate feelings of fear among the citizens"; "The mass media focus too strongly on sensationalism".

Governmental expert efficacy $(M=3.08, S D=0.98$, alpha $=0.93)$ was measured based on the evaluation of the communication of the Belgian federal government using a four-item semantic differential five-point scale of Mitchell and Olson (1981); these were not competent vs. competent; not experienced vs. experienced; not effective vs. effective; not reliable vs. reliable. Moreover, we also measured the expert efficacy in terms of an evaluation of the communication of the Prime Minister Charles Michel $(M=3.32, S D=1.06$, alpha $=0.94)$, Minister of Internal Affairs Jan Jambon $(M=3.28, S D=1.03$, alpha $=0.92)$, and Minister of Justice Koen Geens $(M=3.16, S E=0.96$, alpha $=0.93)$, via a three-item semantic differential five-point scale; these were bad vs. good; with limited expertise vs. with sufficient expertise; dishonest vs. honest.

The cognitive assessment of the risk $(M=3.50, S D=0.87$, alpha $=0.82)$ was measured using the items used by Witte (1992), namely: "The terrorism threat is severe"; "The terrorism threat is risky"; "The likelihood of a terrorist attack to take place in Belgium in the next few weeks is high"; "The likelihood of being hurt myself in a terrorist attack in Belgium in the next few weeks is high".

Negative affective responses $(M=3, S D=1.01$, alpha $=0.75)$ were measured based on the scale of Kahlor (2010) with the items: "I feel fear because of the terrorism threat" and "I feel unsafe because of the terrorism threat".

The items to measure information seeking behavior $(M=3.36, S D=1.17$, alpha $=0.77)$ were also inspired by the measure of Kahlor (2010): "I search for information about the terrorism threat by watching television often" and "I search for information about the terrorism threat by listening to the radio often". We adapted these items by focusing on the two most popular information sources according to our data, namely television and radio.

Behavior in public places was measured based on the scale of Nellis (2009) via the question: "To what extent do you change your behavior because of the terrorism threat in terms of: taking public transport; participating in mass events; being alert in public places; and letting your children participate in school and sports activities". The possible categories for answers 
Table 1

Frequency table of behavior in public activities.

\begin{tabular}{|c|c|c|c|}
\hline & \multicolumn{3}{|c|}{ Behavior in public activities } \\
\hline & Change in behavior & $\begin{array}{l}\text { Feeling uncomfortable, but } \\
\text { not changing behavior }\end{array}$ & $\begin{array}{l}\text { Refusing to change } \\
\text { behavior }\end{array}$ \\
\hline Travelling by public transport & $21.4 \%$ & $16.5 \%$ & $62.1 \%$ \\
\hline Participating in mass events & $37.9 \%$ & $19.6 \%$ & $42.5 \%$ \\
\hline Being alert in public places & $43.0 \%$ & $22.5 \%$ & $34.5 \%$ \\
\hline Letting children participate in school and sports activities & $25.0 \%$ & $23.3 \%$ & $51.7 \%$ \\
\hline
\end{tabular}

Table 2

Frequencies of channels for information seeking.

\begin{tabular}{ll}
\hline To what extent do you consult the following media for information about the terrorism threat? & \multicolumn{1}{l}{$\%$} \\
\hline Websites of Belgian government & $6.2 \%$ \\
Websites of national newspapers & $15.0 \%$ \\
Other websites & $22.1 \%$ \\
International news sources & $65.7 \%$ \\
Television & $48.3 \%$ \\
Radio & $3.9 \%$ \\
Online discussion boards & $18.2 \%$ \\
Facebook & $4.8 \%$
\end{tabular}

$\%=$ percentage of people who use this medium rather frequently or very frequently.

were: "I do not adapt my behavior at all"; "I feel not comfortable, but do not adapt my behavior"; "I adapt my behavior"; or "Not applicable".

Institutional trust $(M=3.06, S D=0.90$, alpha $=0.74)$ was operationalized based on the scale of ter Huurne et al. (2009) with the items: "The Belgian government is making enough efforts to ensure the safety of citizens"; "The Belgian government had a good preventive policy regarding terrorism"; "In the past, the Belgian government has appropriately dealt with the terrorism threat".

Governmental responsibility $(M=2.88, S D=1.16)$ is measured based on the scale of Griffin, Babin, and Darden (1992): “The government is responsible for the terrorism threat".

The organizational reputation $(M=2.83, S D=1.06$, alpha $=0.95)$ is measured based on a shortened version of the reputation quotient scale of Fombrun, Gardberg, and Barnett (2000) and Fombrun, Gardberg, and Sever (2000): "I have a good feeling about the Belgian federal government"; "I admire and respect the Belgian federal government"; "I have trust in the Belgian federal government".

Finally, the questionnaire also includes some socio-demographical details of the respondents such as age, gender, and area of residence to reflect the fact that Belgium is divided in to different regions (Flanders, Wallonia, and Brussels).

All items, except governmental expert efficacy, the expert efficacy of the different Ministers, and behavior in public places, were measured on a five-point Likert-type scale, where $1=$ totally disagree and 5 = totally agree.

\section{Results}

\subsection{Coping strategies}

$\mathbf{R Q}_{1}$ : With regard to behavior in public places, the results in Table 1 show that the most important behavioral change in public activities because of the terrorism threat is that people are more alert in public places (43\%). Second, 37.9\% of Belgian citizens do not participate in mass events because of the terrorism threat. Furthermore, 25\% do not let their children participate in school and sports activities, and $21.4 \%$ do not travel by public transport because of the threat. Furthermore, when we look at people who feel uncomfortable but do not change their behavior, we can see that they feel the most uncomfortable about letting their children participate in sports and school activities (23.3\%). Finally, the activity that people most refuse to change because of the terrorism threat is travelling by public transport (62.1\%).

$\mathbf{R Q}_{2}$ : When looking at the information seeking behavior of Belgian citizens, the results show that $50 \%$ of people search for information about the terrorism threat several times a day, and 32\% search once a day. Table 2 shows to what extent different media channels were used in order to seek information about the terrorism threat.

The results show that the traditional media channels are the most popular source for information about the terrorism threat. People watch the most television to inform themselves, followed by listening to the radio and checking the websites of national newspapers. With regards to the social media results, while almost one fifth of the respondents check Facebook rather frequently to very frequently to find information about the terrorism threat, Twitter and online discussion boards are much less popular. 


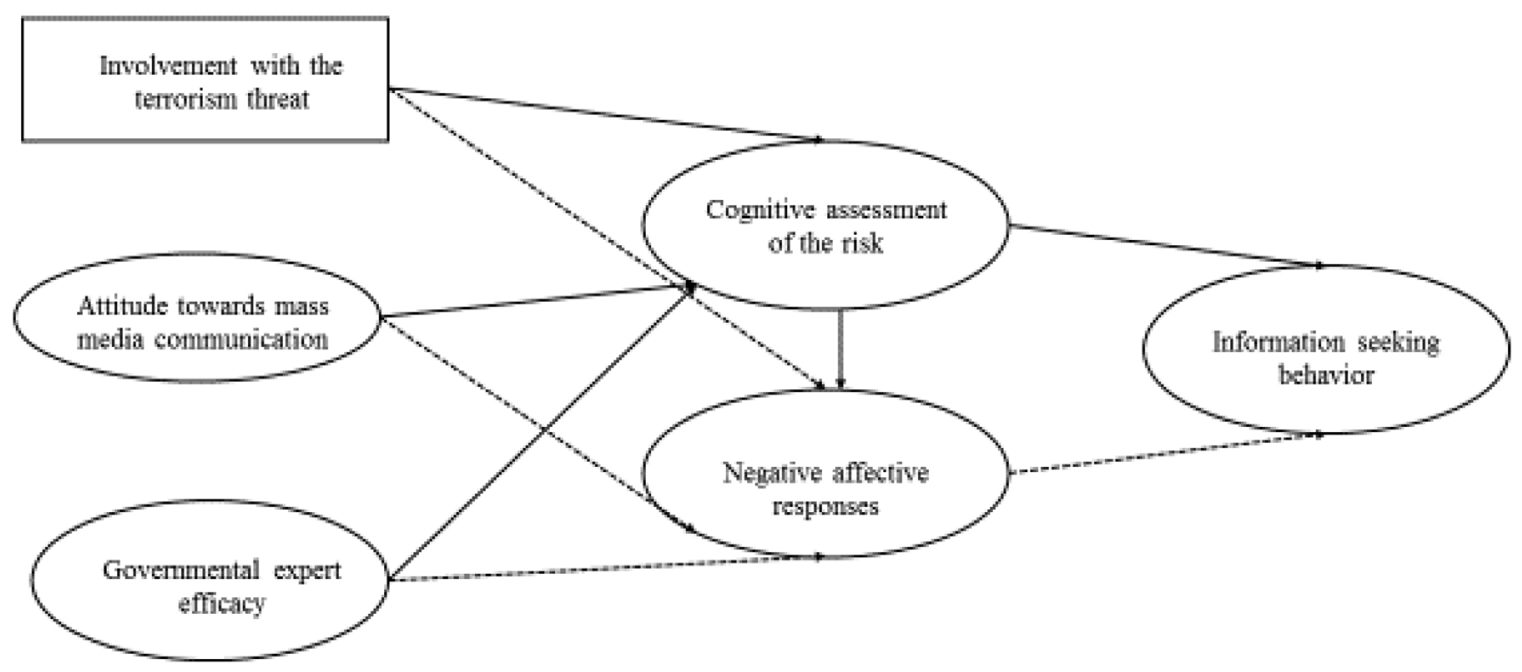

Fig. 3. Structural model of risk information seeking and processing behavior.

The results for the model of information seeking and processing behavior. For the sake of brevity, covariances among exogenous variables and error terms for indicators of latent variables are omitted form the figure. Ovals represent latent variables; rectangles represent measured variables. Full lines represent a significant relationship and dotted lines signify that the relationship is not significant.

\subsection{Determinants of information seeking and processing behavior}

To investigate the proposed information seeking and processing model, structural equation modelling was conducted using AMOS 22.0 software. In the model tested, attitudes towards mass media communication, governmental expert efficacy, cognitive assessment of the risk, negative affective responses, and information seeking behavior were specified as latent variables with multiple indicators, while involvement with the terrorism threat was specified as an observed variable. The maximum likelihood estimation was used to assess missing values.

\subsubsection{Model evaluation criteria}

We evaluated the model fit based on the following indices: the Comparative Fit Index (CFI), the Tucker Lewis Index (TLI) (CFI/TLI > 0.90), and the Root Mean Square of Approximation (RMSEA) $(<0.08)$ (Hu and Bentler, 1999). The $\chi 2$ goodness-offit statistic is reported, as well as an index of model adequacy, where a nonsignificant value indicates good fit. However, because $\chi 2$ has been shown to be sensitive to sample size (Bollen, 1989), the $\chi^{2} / \mathrm{df}$ ratio is reported, where a value less than 3 indicates a good fit $\left(\chi^{2} / \mathrm{df}=\chi^{2}(1)<3.00\right)$ (Kline, 1998).

\subsubsection{Analysis of structural equation modelling}

The proposed model was tested and interpreted in two different stages: (1) an assessment of the construct validity of the measurement model through confirmatory factor analysis (CFA) and (2) the assessment of the structural model (see Men, 2015). The estimation of the initial measurement model indicated a good fit to the data: $\mathrm{X}^{2}(71, N=805)=181.76 ; p<0.001$; $\mathrm{X}^{2} / \mathrm{df}=2.84 ; \mathrm{CFI}=0.98 ; \mathrm{TLI}=0.96 ; \mathrm{RMSEA}=0.05(90 \% \mathrm{CI}=[0.04,0.06])$. However, the co-variances that were added between governmental expert efficacy and involvement appear to be not significant. Hence, we decided to skip this co-variance and re-estimate the model. Results of the re-estimated model again demonstrated a good fit to the data: $\mathrm{X}^{2}(73, N=805)=202.14$; $p<0.001 ; \mathrm{X}^{2} / \mathrm{df}=2.91 ; \mathrm{CFI}=0.98 ; \mathrm{TLI}=0.96 ; \mathrm{RMSEA}=0.05(90 \% \mathrm{CI}=[0.04,0.06])$. Moreover, the standardized factor loadings between latent variables and their indicators ranged from 0.64 to 0.92 , which confirms that the proposed measurement model has good construct validity. Next, we tested the structural model, which also indicated a good fit to the data: $\mathrm{X}^{2}$ (67, $N=805)=195.21 ; p<0.001 ; \mathrm{X}^{2} / \mathrm{df}=2.81 ; \mathrm{CFI}=0.98 ; \mathrm{TLI}=0.96 ; \mathrm{RMSEA}=0.05(90 \% \mathrm{CI}=[0.04,0.06])$. Fig. 3 gives an overview of the structural model. Moreover, in Table 3 the standardized regression weights are shown, as well as the significance level of each relationship. In the following paragraphs the examination of the different research questions and hypotheses based on the model will be explained in detail.

\subsubsection{Test of hypotheses and research questions}

The third research question aimed to find whether a higher involvement with the terrorism threat resulted in a higher cognitive assessment of the threat. Results of the structural model indeed reveal that involvement is positively associated with the cognitive assessment of the risk $(\beta=0.71, \mathrm{p}<0.001)$. However, we found no significant influence of involvement on negative affective responses $(\beta=-0.13, \mathrm{p}>0.05)$. Hence, we can answer the third research question by stating that a higher involvement with the terrorism threat results in a higher cognitive assessment of the risk. However, we must reject $\mathrm{H}_{1}$, which expected a positive relationship between involvement and negative affective responses. 
Table 3

Standardized regression weights of the information seeking and processing model.

\begin{tabular}{lll}
\hline Input variable & Outcome variable & Standardized regression weight \\
\hline Involvement with the terrorism threat & Cognitive assessment of the risk & 0.71 \\
Involvement with the terrorism threat & Negative affective responses towards the risk & -0.13 \\
Attitude towards mass media communication & Cognitive assessment of the risk & -0.18 \\
Attitude towards mass media communication & Negative affective responses towards the risk & -0.02 \\
Governmental expert efficacy & Cognitive assessment of the risk & 0.10 \\
Governmental expert efficacy & Negative affective responses towards the risk & -0.07 \\
Cognitive assessment of the risk & Negative responses towards the risk & 0.001 \\
Cognitive assessment of the risk & Information seeking behavior & 0.57 \\
Negative affective responses towards the risk & Information seeking behavior & -0.0015 \\
\hline
\end{tabular}

Table 4

Multiple regression results.

\begin{tabular}{|c|c|c|c|c|c|}
\hline & \multicolumn{2}{|c|}{ Unstandardized coefficients } & \multicolumn{3}{|c|}{ Standardized coefficients } \\
\hline & $\mathrm{B}$ & Std. Error & B & $\mathrm{t}$ & Sig. \\
\hline (Constant) & 0.41 & 0.08 & & 5.21 & $<0.001$ \\
\hline $\begin{array}{l}\text { Expert efficacy of Minister of } \\
\text { Internal Affairs (Jan Jambon) }\end{array}$ & 0.21 & 0.03 & 0.22 & 6.16 & $<0.001$ \\
\hline $\begin{array}{l}\text { Expert efficacy of } \\
\text { Minister of Justice (Koen Geens) }\end{array}$ & 0.16 & 0.03 & 0.15 & 4.66 & $<0.001$ \\
\hline $\begin{array}{l}\text { Expert efficacy of } \\
\text { Prime Minister (Charles Michel) }\end{array}$ & 0.46 & 0.03 & 0.49 & 14.20 & $<0.001$ \\
\hline
\end{tabular}

In the second hypothesis, we proposed that more negative perceptions of the communications relating to the terrorism threat by the mass media, the lower their cognitive assessment of the risk $\left(\mathrm{H}_{2 \mathrm{a}}\right)$ and negative affective responses will be $\left(\mathrm{H}_{2 b}\right)$. The results indeed demonstrate that when people perceive mass media communication to be too sensationalist and dramatic, their cognitive risk assessment significantly decreases $(\beta=-0.18, \mathrm{p}<0.001)$. Nevertheless, a bad attitude towards mass media communication has no significant impact on the negative affective responses towards the risk $(\beta=-0.02, p>0.05)$. Consequently, hypothesis $2_{\mathrm{a}}$ can be confirmed based on the results, while hypothesis $2_{\mathrm{b}}$ must be rejected.

The fourth research question examines the impact of governmental expert efficacy on the cognitive assessment of the risk and negative affective responses towards the risk. We found a significant positive relationship between governmental expert efficacy and the cognitive assessment of the risk $(\beta=0.10, p=0.01)$. Hence, the higher people rate the governmental expert efficacy, the higher they assess the risk of the terrorism threat cognitively. Moreover, results also show that there is no significant impact of governmental expert efficacy on negative affective responses towards the risk $(\beta=-0.07, p>0.05)$.

We also investigated, by means of multiple regression analysis, whether the expert efficacy of Prime Minister Charles Michel, Minister of Internal Affairs Jan Jambon, and Minister of Justice Koen Geens significantly predict the general expert efficacy of the Belgian federal government. As shown in Table 4, the expert efficacy of all three of the ministers significantly predicts the general expert efficacy of the Belgian Federal Government. Here, the expert efficacy of the Prime Minister is the strongest significant predictor of general efficacy $(\beta=0.46, p<0.001)$; that of the Minister of Internal Affairs is the second highest $(\beta=0.21, p<0.001)$; and that of the Minister of Justice is the lowest $(\beta=0.16, p<0.001)$.

Then, in hypothesis $3_{\mathrm{a}}$ we expected that a high cognitive assessment of the risk results in more information seeking behavior. The results indeed reveal that the higher people's cognitive assessment of the risk of the terrorism threat, the more they will seek information on the radio and television $(\beta=0.57, p<0.001)$. Moreover, there was a strong positive significant relationship between the cognitive assessment of the risk and negative affective responses $(\beta=0.88, p<0.001)$. However, there was no significant relationship found between negative affective responses towards risk and information seeking behavior $(\beta=-0.15, p>0.05)$. Hence, hypothesis $3_{\mathrm{a}}$ and $3_{\mathrm{b}}$ can be confirmed, while hypothesis $3_{\mathrm{c}}$ must be rejected.

\subsection{Governmental reputation model}

To investigate hypothesis 4 and 5, mediation analyses were conducted, using Preacher and Hayes' (2004) bootstrap test (i.e., model 4), to estimate indirect effects in simple mediation models. In each analysis 5000 bootstrap samples were used in order to estimate a $95 \%$ confidence interval. When zero falls outside the confidence interval this means that the indirect effect is significant and mediation is present.

\subsubsection{Test of hypotheses}

To analyze the fourth hypothesis governmental expert efficacy was added as an independent variable, institutional trust as mediator, and the governmental reputation as a dependent variable. The results indicate a positive significant relationship between governmental expert efficacy and institutional trust $(B=0.82, t=14.36, p<0.001)$, which in turn results in a better governmental reputation $(B=0.58, t=17.69, p<0.001)(B=0.48, S E=0.05 ; 95 \% \mathrm{CI}=[0.40 ; 0.57])$. Furthermore, the direct effect 


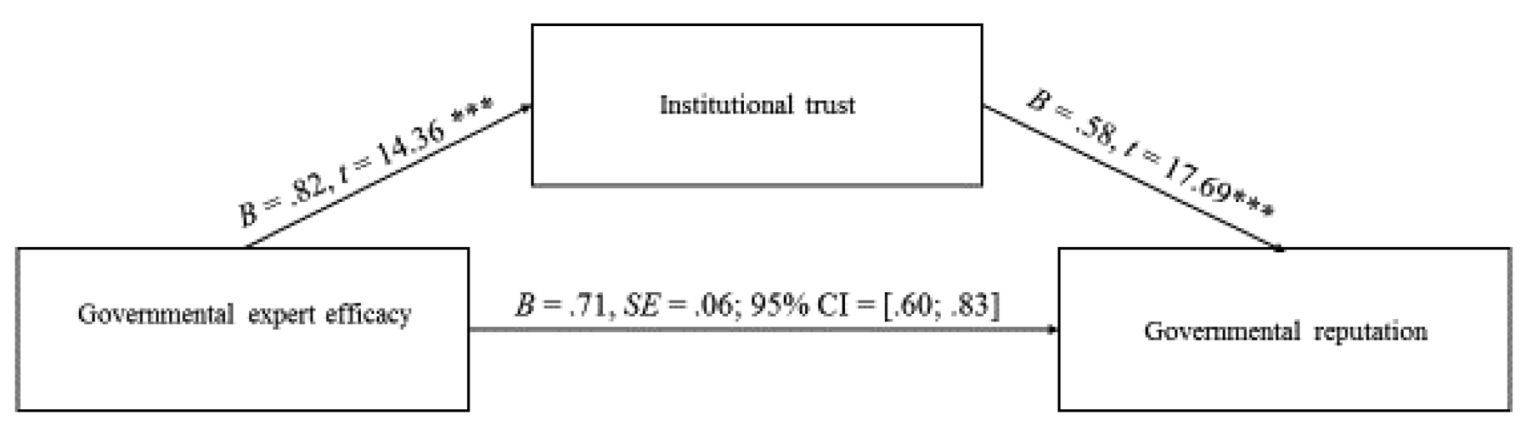

Fig. 4. Model of governmental reputation mediated by institutional trust.

Reported estimates are unstandardized coefficients (see Hayes, 2013) ${ }^{*} \mathrm{p}<0.05,{ }^{* *} \mathrm{p}<0.01,{ }^{* * *} \mathrm{p}<0.001$.

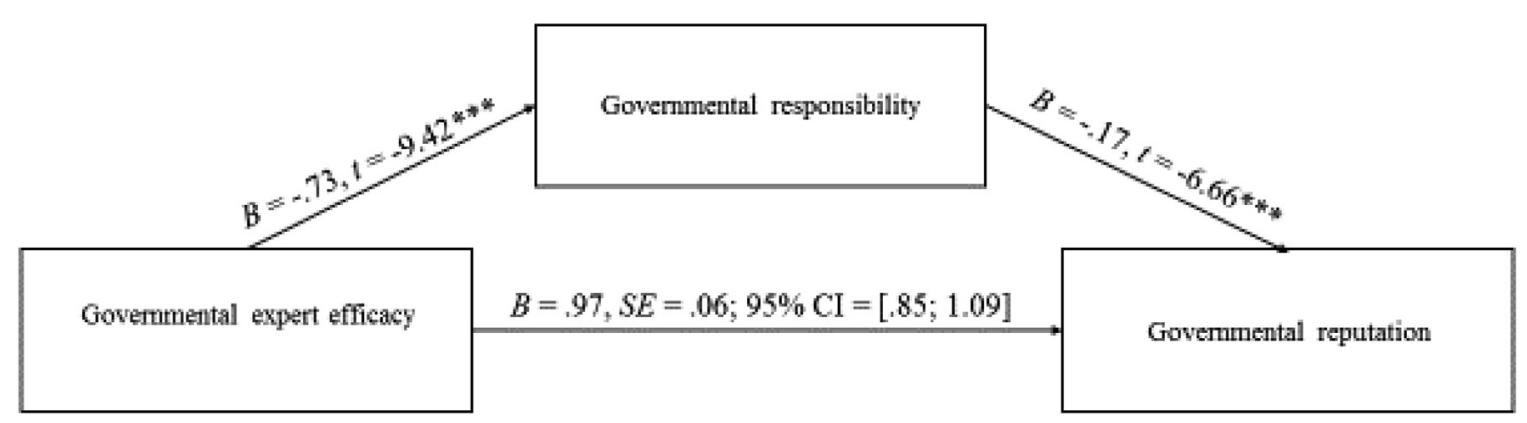

Fig. 5. Model of governmental reputation mediated via governmental responsibility.

Reported estimates are unstandardized coefficients (cf. Hayes, 2013) ${ }^{*} \mathrm{p}<0.05,{ }^{* *} \mathrm{p}<0.01,{ }^{* * *} \mathrm{p}<0.001$.

Table 5

Overview testes hypotheses.

\begin{tabular}{ll}
\hline Hypothesis & Results \\
\hline $\mathrm{H}_{1}$ & Rejected \\
$\mathrm{H}_{2 \mathrm{a}}$ & Confirmed \\
$\mathrm{H}_{2 \mathrm{~b}}$ & Rejected \\
$\mathrm{H}_{3 \mathrm{a}}$ & Confirmed \\
$\mathrm{H}_{3 \mathrm{~b}}$ & Confirmed \\
$\mathrm{H}_{3 \mathrm{c}}$ & Rejected \\
$\mathrm{H}_{4}$ & Confirmed \\
$\mathrm{H}_{5}$ & Confirmed \\
\hline
\end{tabular}

of governmental expert efficacy on governmental reputation was also significant $(B=0.71, S E=0.06 ; 95 \% \mathrm{CI}=[0.60 ; 0.83])$. Fig. 4 gives a schematic overview of the results.

In order to analyze the last hypothesis, governmental expert efficacy was again added as an independent variable, governmental responsibility as mediator, and the governmental reputation as a dependent variable. Results indicate a negative significant relationship between governmental expert efficacy and governmental responsibility $(B=-0.73, t=-9.42$, $p<0.001)$, which in turn results in a better governmental reputation $(B=-0.17, t=-6.66, p<0.001)(B=0.12, S E=0.03$; $95 \% \mathrm{CI}=[0.08 ; 0.18])$. Furthermore, the direct effect of governmental expert efficacy on governmental reputation was also significant $(B=0.97, S E=0.06 ; 95 \% \mathrm{CI}=[0.85 ; 1.09])$. The results are briefly summarized in Fig. 5.

To conclude, Table 5 gives an overview of which hypotheses are confirmed and rejected.

\section{Conclusion and discussion}

\subsection{Key findings}

The aim of the current case-study was threefold. First, we wanted to investigate how Belgians try to cope with the risk of the terrorism threat. We examined this based on two different behavioral activities, namely behavior in public places and information seeking behavior. Second, we elaborated on why Belgians engage in information seeking and processing behavior based on three determinants, namely involvement with the threat, attitude towards mass media communication, and governmental expert efficacy. Based on SEM we analyzed how these three concepts determine the cognitive and affective 
assessment of the risk and subsequent information seeking behavior. Third, we investigated how perceived governmental efficacy affected governmental reputation via institutional trust and governmental responsibility.

Results demonstrate that Belgians are mostly more alert in public places because of the terrorism threat. Furthermore, almost four out of ten people no longer participate in mass events because of the threat, and one fifth are afraid to travel by public transport. Finally, a quarter also restrict their children's to participation in school and sports activities. Moreover, results also reveal that people often engage in information seeking behavior to deal with the terrorism threat, with $50 \%$ of people searching for information several times a day. The most popular channels are traditional media channels such as television and radio, and almost one fifth make use of Facebook to search for information.

Furthermore, the proposed information seeking and processing model showed that Belgians primarily deal with the terrorism threat on a cognitive level by assessing the severity and susceptibility of the risk, which in turn influences their information seeking behavior. We found that when people's cognitive assessment of the terrorism threat is higher, they will have more negative affective responses to it which confirms the findings Griffin et al. (2004). Moreover, we also found that a higher cognitive assessment of the terrorism threat resulted in more information seeking and processing behavior, as was recently found by Kievik et al. (2012). Hence, these findings are in line with previous research. However, unlike our expectations, higher negative affective responses do not result in more information seeking behavior as suggested by Griffin et al. (1999) and ter Huurne (2008). This might be possibly explained by the fact that efficacy is not integrated in the current model. Further research is necessary to clarify this finding. Nevertheless, based on the results of this study we could state that the coping process of Belgians to deal with the uncertainties initiated by the terrorism threat is primarily on a cognitive and not on an affective level. However, it is important to note that according to the EPPM, this will only be the case for people who believe that they are able to seek information about the terrorism threat (high self-efficacy) and that this information seeking is effective in reducing the fear related to the threat (high response-efficacy). When people doubt that seeking more information will help to reduce fear and/or they are not able to do so, they will be motivated to control their fear rather than their exposure to the danger of the threat. These people will engage in denial, "I am not at risk to be affected by a terrorist attack in Belgium"; defensive avoidance, "this is too scary, I am not going to think about it"; or reactance, "they're just trying to manipulate me, I will ignore them" (Witte, 1992). Hence, for future research it is important to include these variables as well.

Moreover, according to the results people make lower cognitive assessments of the terrorism threat, in terms of susceptibility and severity, when they feel low involvement with the threat; rate the expert efficacy of the government as high; and have a bad attitude towards the communication of the mass media. More specifically, the results show that a higher involvement with the terrorism threat results in a higher cognitive assessment of the risk, but not in more negative affective responses. Hence, on one hand, the fact that the terrorism threat is personally relevant to a person and his loved ones does not lead him or her to feel more frightened or unsafe, but on the other hand, does make him or her more cognitively aware of the risk. This confirms the claim made by Petty and Cacioppo (1986), who state that highly involved people will put more effort into processing information and thereby become more aware of the risk. Nevertheless, our findings contradict Ter Huurne and Gutteling's (2008) suggestion that higher involvement results in higher negative affective responses.

Interestingly, with regard to the perceptions about the communication of the terrorism threat, our model showed that when people think that the media focus too strongly on sensationalism, their cognitive assessment of the risk decreases. This result seems to provide more evidence for the fact that mass media coverage is indeed very influential (see Krewski et al., 2006). This is an important contribution to existing research, which has so far been indecisive about the impact of the beliefs of those who provide risk information (see Griffin et al., 2004). Again, data showed a significant influence on the cognitive assessment of the risk, but not on the affective assessment of the risk. Further research is necessary to clarify which are the underlying drivers of this primary cognitive appraisal.

Next, we also found that the better the perceived governmental efficacy, the higher was people's cognitive assessment of the risk. This finding sounds rather contra-intuitive; one would expect that when people rate the expert efficacy of the government high that they trust the government in handling the risk properly and therefore have a lower risk perception. This finding could possibly be because we examined the impact of the expert efficacy of the government in general and not of the ministers who represent the government. Another possible explanation is that Belgians have trust in the experts representing the government, but their evaluation of the response-efficacy is low. However, from another perspective, this finding might also provide evidence for the fact that the Belgian federal government to an extent did a good job by making people aware of the risk. After all, they were not able to significantly reduce a feeling of unsafety by their communication. Hence, the difficult balance between inducing a culture of fear and creating awareness must be optimized in the future when confronted with similar uncertain events (Altheide, 2006; Mythen \& Walklate, 2006). Furthermore, the results also demonstrated that the Prime Minister is the most important communicator representing the federal government. People rate the expert efficacy of the Minister of Justice the lowest. This might possibly be explained by the fact that he or she has to communicate about police and legal action, which are very delicate topics. The minister is obliged to be somehow vague about these actions in order to avoid interrupting them.

Finally, we also explored how governmental reputation is influenced by the perceived governmental expert efficacy. Namely, when a risk is uncontrollable, people have the need to know that the government is doing as much as possible to control the threat (Ter Huurne \& Gutteling, 2008). We found that a high expert efficacy rating is indeed able to protect governmental reputation because it enhances institutional trust, which is a crucial factor of risk communication (Heath \& Palenchar, 2007; Liu et al., 2016; Renn, 2006; Ter Huurne \& Gutteling, 2008). Moreover, it also decreases the level of respon- 
sibility attributed to the government for the terrorism threat, which is in turn beneficial for the governmental reputation. Hence, it is important for organizations to put time and effort in their expertise, as this is not only able to increase the level of trust but also the decrease the attributed responsibility. The results seem to provide evidence that organizations are able to protect their reputation by putting effort in to honest, clear, and open communication (Burke, 1999; Fombrun \& Rindova, 1998).

\subsection{Managerial implications}

In sum, this study reveals several important implications for communication managers who have to deal with a highly uncertain situation such as a terrorism threat. First of all, when confronted with a terrorism threat, people seem to engage in information seeking behavior in order to deal with the threat. Hence, it is important for communication managers to provide information to the public on a regular basis in order to enhance the public's feeling of control over the risk. Moreover, it is important not to overlook traditional media as providers of information because, despite the current digital environment, these media remain very popular. Facebook is also an important information channel, while Twitter seem to be less important.

Moreover, people tend to deal with the threat primarily in a cognitive way. Hence, it is important to pay attention to how people assess the severity of the risk and the likelihood of being involved in an attack themselves. Therefore, communication managers have to try to shape this cognitive assessment by making people aware of the severity of the risk, while not creating panics and chaos by saying that the likelihood of being involved in the risk is quite low. Moreover, the study shows that it is important for communication managers to divide the public into people who have low and high involvement, based on how close they live to the affected area for example. This is because those with high involvement assess the risk to be higher than those who have low involvement. Furthermore, it is also important to pay attention to how the risk is framed in the mass media; when the mass media focus too much on sensationalism, this decreases people's risk perception. Next, through governmental communication the government is able to make people cognitively aware of the risk. The Prime Minister tends to be the most trusted expert representing the government. Hence, for governments confronted with similar events it is advisable to let him or her be the primary communicator and represent the government in general.

Finally, results also show that governments are able to protect their reputation by communicating in an adequate manner to the public. Governments have to strive for communication that reflects reliability, experience, and honesty. This is beneficial to their reputation in two ways, increasing trust and decreasing responsibility for the threat. In conclusion, this study highlights the important role that providing information via communication can play in a risk or crisis context. Hence, it is important for organizations to have competent and skilled public relations practitioners who are able to make the appropriate communication efforts in situations marked by high uncertainty.

\section{Limitations and future directions}

Although this study provides some interesting insights, some limitations should be recognized, which form valuable suggestions for further research. First, the study was conducted soon after the terrorist threat level in Belgium was raised to the highest level possible. In order to gain accurate insights into the perceptions of Belgian residents regarding the terrorism threat, we have chosen to focus on several concepts instead of integrating all possible relevant concepts into a long and extensive survey. The purpose of this study was to make a case study and not in-depth research that takes into account all possible influencing factors. As a result, the information seeking and processing model used do not give a comprehensive overview of all possible influencing factors. Hence, further research is necessary to test a complete model, which includes all the relevant variables, such as self-efficacy, response-efficacy, and interpersonal sources of risk information in the context of information seeking and processing behavior. For example, future research might consider other sources that provide information to the public about risk, such as local emergency planning committees and interpersonal sources of information (family or friends). Prior research has shown that before and during a crisis event, people prefer to have a range of communication sources (Heath et al., 2009; Heath, Bradshaw, \& Lee, 2002). Hence, for future research it could be interesting to examine the interaction between timing and different sources of information. In addition, in this study expert efficacy was operationalized based on the evaluation of the communication of the experts. However, people could also evaluate the expert efficacy based on the actions instead of the words of the experts. Hence, in future research it would be interesting to investigate the evaluation of the actions recommended by the experts as well. Furthermore, this study was a case-study and focused on a highly uncontrollable and unpredictable crisis. Further research is necessary to clarify the impact of the researched variables in other risk and crisis contexts. In addition, it might also be interesting to investigate the impact of risk tolerance, as people may differ in their tolerance to certain risks, which in turn could influence their risk perceptions and consequent behavior. Finally, it could also be interesting to track the measures of this study longitudinally by following the evolution of the threat. On the 22nd of March 2016 terrorism was no longer a threat but a reality in Belgium, as terrorists attacked the national airport and a metro station. It would be interesting to examine how the assessment of the risk of terrorism has evolved due to this event.

\section{References}

Altheide, D. L. (2006). Terrorism and the politics of fear. Lanham: AltaMira Press, Amoore. 
Andrews, J. C., Durvasula, J. C., \& Akhter, S. H. (1990). A framework for conceptualizing and measuring the involvement construct in advertising research. Journal of Advertising, 19(4), 27-40. http://dx.doi.org/10.1080/00913367.1990.10673198

Bergmans, E. (2015, November 15). De feiten op een rij. De Standaard. Retrieved from: http://www.standaard.be/cnt/dmf20151114_01970760.

Bollen, K. A. (1989). Structural equations with latent variables. John Wiley \& Son.

Burke, F. (1999). Ethical decision-making: Global concerns, frameworks and approaches. Public Personnel Management, 28(4), 529-540. http://dx.doi.org/10.1177/009102609902800404

Carpenter, A. (2015). Resilience in the social and physical realms: Lessons from the gulf coast. International Journal of Disaster Risk Reduction, 14(3), 290-301. http://dx.doi.org/10.1016/j.ijdrr.2014.09.003

Cho, H., \& Boster, F. J. (2005). Development and validation of value-, outcome-, and impression relevant involvement scales. Communication Research, 32(2), 235-264. http://dx.doi.org/10.1177/0093650204273764

Claeys, A.-S., Cauberghe, V., \& Vyncke, P. (2010). Restoring reputations in times of crisis: An experimental study of the Situational Crisis Communication Theory and the moderating effects of locus of control. Public Relations Review, 36(3), 256-262. http://dx.doi.org/10.1016/j.pubrev.2010.05.004

Coombs, W. T., \& Holladay, S. J. (1996). Communication and attributions in a crisis: An experimental study in crisis communication. Journal of Public Relations Research, 8(4), 279-295. http://dx.doi.org/10.1207/s1532754xjprr0804_04

Coombs, W. T. (2007). Protecting organization reputations during a crisis: The development and application of situational crisis communication theory. Corporate Reputation Review, 10(3), 163-176. http://dx.doi.org/10.1057/palgrave.crr.1550049

Covello, V. T., Peters, R. G., Wojtecki, J. G., \& Hyde, R. C. (2001). Risk communication, the West Nile virus epidemic and bioterrorism: Responding to the communication challenges posed by the intentional or unintentional release of a pathogen in an urban setting. Journal of Urban Health-Bulletin of the New York Academy of Medicine, 78(2), 382-391. http://dx.doi.org/10.1093/jurban/78.2.382

De Vocht, M. (2014). How to communicate risks to the public? Research on risk communication about food safety of fresh produce. In Unpublished doctoral dissertation. Ghent University, Ghent.

Dean, D. H. (2004). Consumer reaction to negative publicity: Effects of corporate reputation, response, and responsibility for a crisis event. Journal of Business Communication, 41(2), 192-211. http://dx.doi.org/10.1177/0021943603261748

Eeckhaut, M., Vanhecke, N., \& Tack, H. (2015, January 15). Twee doden bij antiterrorisme-actie in Verviers. De Standaard. Retrieved from: http://www.destandaard.be.

Eurobarometer (2015, January 18). Europeans' attitudes towards security. Retrieved from the World Wide Web: https://open-data.europa.eu/nl/data/dataset/S2085_83_2_432_ENG.

Fombrun, C. J., Gardberg, N. A., \& Barnett, M. L. (2000). Opportunity platforms and safety nets: Corporate citizenship and reputational risk. Business and Society Review, 105(1), 85-106. http://dx.doi.org/10.1111/0045-3609.00066

Fombrun, C. J., Gardberg, N. A., \& Sever, J. M. (2000). The reputation quotient sm: A multi-stakeholder measure of corporate reputation. The Journal of Brand Management, 7(4), 241-255. http://dx.doi.org/10.1057/bm.2000.10

Ford, N. (2004). Modeling cognitive processes in information seeking and processing: From popper to pask. Journal of the American Society For Information Science and Technology, 55(9), 769-782. http://dx.doi.org/10.1002/asi.20021

Frisby, B. N., Veil, S. R., \& Sellnow, T. L. (2014). Instructional messages during health-related crises: Essential content for self-protection. Health Communication, 29(4), 347-354. http://dx.doi.org/10.1080/10410236.2012.755604

Ganor, M., \& Ben-Lavy, Y. (2003). Community resilience: Lessons derived from Gilo under fire. Journal of Jewish Communal Service, (Winter/Spring), $105-108$.

Gilles, I., Bangerter, A., Clemence, A., Green, E. G. T., Krings, F., Staerkle, C., et al. (2011). Trust in medical organizations predicts pandemic (H1N1): 2009 vaccination behavior and perceived efficacy of protection measures in the Swiss public. European Journal of Epidemiology, 26, 203-210. http://dx.doi.org/10.1007/s10654-011-9577-2

Gorney, C. (1992). Numbers versus pictures: Did network television sensationalize Chernobyl coverage? Journalism Quarterly, 69(2), 455-465. http://dx.doi.org/10.1177/107769909206900219

Gray, G. M., \& Ropeik, D. P. (2002). Dealing with the dangers of fear: The role of risk communication. Health Affairs, 21(6), 106-116. http://dx.doi.org/10.1377/hlthaff.21.6.106

Griffin, M., Babin, B. J., \& Darden, W. R. (1992). Consumer assessments of responsibility for product-related injuries: The impact of regulations, warnings, and promotional policies. Advances in Consumer Research, 19(1), 870-878. http://dx.doi.org/10.1016/0148-2963(91)90014-o

Griffin, R. J., Dunwoody, S., \& Neuwirth, K. (1999). Proposed model of the relationship of information seeking and processing and processing to the development of preventive behaviors. Environmental Research, 80(2), 230-245. http://dx.doi.org/10.1006/enrs.1998.3940

Griffin, R. J., Powell, M., Dunwoody, S., Neuwirth, K., Clark, D., \& Novotny, V. (2004). Testing the robustness of a risk information processing model. In Paper presented to the communication theory and methodology division.

Griffin, R. J., Yang, Z., Ter Huurne, E., Boerner, F., Ortiz, S., \& Dunwoody, S. (2008). After the flood: Anger, attribution and the seeking of information. Communication Science, 29(3), 285-315. http://dx.doi.org/10.1177/1075547007312309

Grunig, J. E. (1989). Sierra club study shows who become activists. Public Relations Review, 15(3), 3-24. http://dx.doi.org/10.1016/S0363-8111(89)80001-3

Hayes, A. F. (2013). An introduction to mediation, moderation, and conditional process analysis: A regression-based approach. New York, NY: Guilford Press.

Heath, R. L., \& Douglas, W. (1991). Effects of involvement on reactions to sources of messages and to message clusters. In L. A. Grunig, \& J. E. Grunig (Eds.), Public relations research annual (Vol. 3) (pp. 179-193). Hillsdale, NJ: Lawrence Erlbaum Associates, Inc.

Heath, R. L., \& Lee, J. (2015). Chemical manufacturing and refining industry legitimacy: Reflective management, trust, precrisis communication to achieve community efficacy. Risk Analysis, 36(6), 1108-1124. http://dx.doi.org/10.1111/risa.12504

Heath, R. L., \& Palenchar, M. (2007). Strategic risk communication: Adding value to society. Public Relations Review, 33(2), 120-129. http://dx.doi.org/10.1016/j.pubrev.2006.11.014

Heath, R. L., Liao, S. H., \& Douglas, W. (1995). Effects of perceived economic harms and benefits on issue involvement, use of information sources, and actions: A study in risk communication. Journal of Public Relations Research, 7(2), 87-109. http://dx.doi.org/10.1207/s1532754xjprr0702_01

Heath, R. L., Bradshaw, J., \& Lee, J. (2002). Community relationship building: Local leadership in the risk communication infrastructure. Journal of Public Relations Research, 14(4), 317-353. http://dx.doi.org/10.1207/S1532754XJPRR1404_2

Heath, R. L., Lee, J., \& Ni, L. (2009). Crisis and risk approaches to emergency management planning and communication: The role of similarity and sensitivity. Journal of Public Relations Research, 21(2), 123-141. http://dx.doi.org/10.1080/10627260802557415

Heath, R. L. (1997). Strategic issues management: Organizations and public policy challenges. Thousand Oaks, CA: Sage.

Hosking, G. (2009). Terrorism and trust. Critical Studies on Terrorism, 2(3), 482-496. http://dx.doi.org/10.1080/17539150903306204

Hu, L.-T., \& Bentler, P. M. (1999). Cutoff criteria for fit indexes in covariance structure analysis: Conventional criteria versus new alternatives. Structural Equation Modeling: A Multidisciplinary Journal, 6, 1-55. http://dx.doi.org/10.1080/10705519909540118

Innes, M. (2006). Policing uncertainty: Counter terror through community intelligence and democratic policing. The ANNALS of the American Academy of Political and Social Science, 605(1), 222-241. http://dx.doi.org/10.1177/0002716206287118

Kahlor, L., Dunwoody, S., Griffin, R. J., \& Neuwirth, K. (2006). Selecting and processing information about impersonal risk. Science Communication, 28(2), 163-194. http://dx.doi.org/10.1177/1075547006293916

Kahlor, L. (2010). PRISM: A planned risk information seeking and processing model. Health Communication, 25(4), 345-356. http://dx.doi.org/10.1080/10410231003775172

Kasperson, R. E., \& Kasperson, J. X. (1996). The social amplification and attenuation of risk. Annals of the American Academy of Political and Social Science, 545(1), 95-105. http://dx.doi.org/10.1177/0002716296545001010 
Kasperson, R. E. (1992). The social amplification of risk: Progress in developing an integrative framework. In S. Krimsky, \& D. Golding (Eds.), Social theories of risk (pp. 153-178). Westport, CT: Praeger.

Kelley, H. (1973). The processes of causal attribution. American Psychologist, 28(2), 107-128. http://dx.doi.org/10.1037/h0034225

Kievik, M., \& Gutteling, J. M. (2011). Yes, we can: Motivate Dutch citizens to engage in self-protective behavior with regard to flood risks. Natural Hazards, 59(3), 1475-1490. http://dx.doi.org/10.1007/s11069-011-9845-1

Kievik, M., Ter Huurne, E. F. J., \& Gutteling, J. M. (2012). The action suited the word? Use of the framework of risk information seeking to understand risk-related behaviors. Journal of Risk Research, 15(2), 131-147. http://dx.doi.org/10.1080/13669877.2011.601318

Kline, R. B. (1998). Principles and practice of structural equation modeling. New York: Guilford.

Krewski, D., Lemyre, L., Turner, M. C., Lee, J. E. C., Dallaire, C., Bouchard, L., et al. (2006). Public perception of population health risks in Canada: Health hazards and sources of information. Human and Ecological Risk Assessment, 12(4), 626-644. http://dx.doi.org/10.1080/10807030600561832

Kunreuther, H., Easterling, D., Desvousges, W., \& Slovic, P. (1990). Public attitudes toward siting a high-level nuclear waste repository in Nevada. Risk Analysis, 10(4), 469-484. http://dx.doi.org/10.1111/j.1539-6924.1990.tb00533.x

Kunreuther, H. (2002). Risk analysis and risk management in an uncertain world. Risk Analysis, 22(4), 644-664. http://dx.doi.org/10.1111/0272-4332.00057

Lee, J. E. C., \& Lemyre, L. (2009). A social-cognitive perspective of terrorism risk perception and individual response in Canada. Risk Analysis, 29(9), 1265-1280. http://dx.doi.org/10.1111/j.1539-6924.2009.01264.x

Lee, J. E. C., Gibson, S., Markon, M.-P. L., \& Lemyre, L. (2009). A preventive coping perspective of individual response to terrorism in Canada. Current Psychology, 28(2), 69-84. http://dx.doi.org/10.1007/s12144-009-9053-2

Liu, B. F., \& Fraustino, J. D. (2014). Beyond image repair: Suggestions for crisis communication theory development. Public Relations Review, 40(3), 543-546. http://dx.doi.org/10.1016/j.pubrev.2014.04.004

Liu, B., Bartz, L., \& Duke, N. (2016). Communicating crisis uncertainty: A review of the knowledge gaps. Public Relations Review, $42(3)$, $479-487$. http://dx.doi.org/10.1016/j.pubrev.2016.03.003

Longstaff, P. H., \& Yang, S.-U. (2008). Communication management and trust: Their role in building resilience to surprises such as natural disasters, pandemic flue and terrorism. Ecology and Society, 13(1), 1-15.

McComas, K. A. (2006). Defining moments in risk communication research: 1996-2005. Journal of Health Communication, 11(1), 75-91. http://dx.doi.org/10.1080/10810730500461091

Men, L. R. (2015). The internal communication role of the chief executive officer: Communication channels, style, and effectiveness. Public Relations Review, 41(4), 461-471. http://dx.doi.org/10.1016/j.pubrev.2015.06.021

Mitchell, A. A., \& Olson, J. C. (1981). Are product attribute beliefs the only mediator of advertising effects on brand attitude? Journal of Marketing Research, 18(3), 318-332. http://dx.doi.org/10.2307/3150973

Mythen, G., \& Walklate, S. (2006). Communicating the terrorist threat: Harnessing a culture of fear? Crime Media Culture, 2(2), 123-142. http://dx.doi.org/10.1177/1741659006065399

Nellis, A. (2009). Gender differences in fear of terrorism. Journal of Contemporary Criminal Justice, 25(3), 322-340. http://dx.doi.org/10.1177/1043986209335012

Norris, F., Stevens, S., Pfefferbaum, B., Wyche, K. F., \& Pfefferbaum, R. L. (2008). Community resilience as a metaphor, theory, set of capacities, and strategy for disaster readiness. American Journal of Community Psychology, 4(1-2), 127-150. http://dx.doi.org/10.1007/s10464-007-9156-6

Palenchar, M. J., \& Heath, R. L. (2002). Another part of the risk communication model: Analysis of risk communication process and message content. Journal of Public Relations Research, 14(2), 127-158. http://dx.doi.org/10.1207/S1532754XJPRR1202

Palenchar, M. J., Heath, R. L., \& Orberton, E. M. (2005). Terrorism and industrial chemical production: A new era of risk communication. Communication Research Reports, 22(1), 59-67. http://dx.doi.org/10.1080/0882409052000343525

Patin, B. (2015). Through hell and high water: A librarian's autoethnography of community resilience after hurricane Katrina. MediaTropes eJournal, 5(2), 58-83. http://dx.doi.org/10.1080/1366271042000200448

Petty, R. E., \& Cacioppo, J. T. (1981). Attitudes and persuasion: Classic and contemporary approaches. Dubuque, IA: Brown.

Petty, R. E., \& Cacioppo, J. T. (1986). Communication and persuasion: Central and peripheral routes to attitude change. NewYork: Springer.

Preacher, K. J., \& Hayes, A. F. (2004). SPSS and SAS procedures for estimating indirect effects in simple mediation models. Behavior Research Methods, Instruments, E' Computers: A Journal of the Psychometric Society, Inc, 36(4), 717-731. http://dx.doi.org/10.3758/bf03206553

Quinn, S. C., Kumar, S., Freimuth, V. S., Kidwell, K., \& Musa, D. (2009). Public willingness to take a vaccine or drug under emergency use authorization during the 2009H1N1 pandemic. Biosecurity and Bioterrorism: Biodefense Strategy, Practice, and Science, 11(2), $275-290$. http://dx.doi.org/10.1089/bsp.2009.0041

Renn, O. (2006). Risk communication: Consumers between information and irritation. Journal of Risk Research, 9(8), 833-849. http://dx.doi.org/10.1080/13669870601010938

Rindova, V., \& Fombrun, C. (1998). The eye of the beholder: The role of corporate reputation in defining organizational identity. In D. Whetten, \& P. Godfrey (Eds.), Identity in organizations: Building theory through conversations (pp. 62-66). Thousand Oaks, CA: Sage Publ. Inc.

Rogers, R., Amlôt, M. B., Rubin, G. J., Wessely, S., \& Krieger, K. (2007). Mediating the social and psychological impacts of terroristic attacks: The role of risk perception and risk communication. International Journal of Psychiatry, 19(3), 279-288. http://dx.doi.org/10.1080/09540260701349373

Rose, M., \& Blenkinsop P. (2015, November 25). France, Belgium widen probe into Parisian attacks, Hollande meets Obama. Reuters. Retrieved from: http://www.reuters.com.

Rubin, G., Brewin, C. R., Greenberg, N., Simpson, J., \& Wessely, S. (2005). Psychological and behavioral reactions to the bombings in London on 7 July 2005 : cross-sectional survey of a representative sample of Londoners. BMJ, 331(7517), 606-613. http://dx.doi.org/10.1136/bmj.38583.728484.3A

Sandman, P. M. (1994). Mass media and environmental risks: Seven principles. Risk: Health, Safety, E' Environment, $275-284$. http://dx.doi.org/10.1016/b978-0-08-052100-8.50022-1

Shore, D. A. (2003). Communicating in times of uncertainty: The need for trust. Journal of Health Communication: International Perspectives, 8(1), 13-14 http://dx.doi.org/10.1080/713851977

Siegrist, M., Cvetkovich, G., \& Roth, C. (2000). Salient value similarity, social trust, and risk/benefit perception. Risk Analysis, 20 (3), $353-362$. http://dx.doi.org/10.1111/0272-4332.203034

Signorielli, N. (1993). Mass media images and the impact on health: A sourcebook. Westport, CT: Greenwood Press.

Slovic, P., Finucane, M., Peters, E., \& Macgregor, D. G. (2004). Risk as analysis and risk as feelings: Some thoughts about affect, reason, risk and rationality. Risk Analysis, 24(2), 311-322. http://dx.doi.org/10.1111/j.0272-4332.2004.00433.x

Slovic, P. (1987). Perception of risk. Science, 236(4799), 280-285. http://dx.doi.org/10.1126/science.3563507.4

Stevens, I. (2010). New public oriented risk communication in the new risk society. Unpublished doctoral dissertation: University of Ghent.

Ter Huurne, E. F. J., \& Gutteling, J. M. (2008). Information needs and risk perception as predictors of risk information seeking and processing. Journal of Risk Research, 11(7), 847-862. http://dx.doi.org/10.1080/13669870701875750

ter Huurne, E. F. J., Griffin, R. J., \& Gutteling, J. M. (2009). Risk information seeking and processing among U.S. and Dutch residents. Science Communication, 31, 215-237. http://dx.doi.org/10.1177/1075547009332653

ter Huurne, E. F. J. (2008). Information seeking and processing in a risky world. The theoretical and empirical development of FRIS: A Framework of Risk Information seeking and processing and Processing. In Unpublished doctoral dissertation. University of Twente.

Watson, T. (2007). Reputation and ethical behavior in a crisis: Predicting survival. Journal of Communication Management, 11(4), 371-384. http://dx.doi.org/10.1108/13632540710843959 
Witte, K. (1992). Putting fear back into fear appeals: The extended parallel processing model. Communication Monographs, 59(4), 329-349. http://dx.doi.org/10.1080/03637759209376276

Wray, R. J., Kreuter, M. W., Jacobsen, H., Clements, B., \& Evans, R. G. (2004). Theoretical perspectives on public communication preparedness for terrorist attacks. Family \& Community Health, 27(3), 232-241. http://dx.doi.org/10.1097/00003727-200407000-00010

Yang, Z. (2012). Too scared or too capable? Why do college students stay away from the H1N1 Vaccine? Risk Analysis, 32(10), 1703-1716. http://dx.doi.org/10.1111/j.1539-6924.2012.01799.x 